\title{
Measurement of Tritium in Gas Phase Soil Moisture and Helium-3 in Soil Gas at the Hanford Townsite and $100 \mathrm{~K}$ Area
}
K. B. Olsen
P. E. Dresel
G. W. Patton
J. C. Evans
R. Poreda ${ }^{(a)}$

June 2000

Prepared for

the U.S. Department of Energy

under Contract DE-AC06-76RLO 1830

Pacific Northwest National Laboratory

Richland, Washington 99352

(a) University of Rochester, Rochester, New York 



\section{DISCLAIMER}

This report was prepared as an account of work sponsored by an agency of the United States Government. Neither the United States Government nor any agency thereof, nor any of their employees, make any warranty, express or implied, or assumes any legal liability or responsibility for the accuracy, completeness, or usefulness of any information, apparatus, product, or process disclosed, or represents that its use would not infringe privately owned rights. Reference herein to any specific commercial product, process, or service by trade name, trademark, manufacturer, or otherwise does not necessarily constitute or imply its endorsement, recommendation, or favoring by the United States Government or any agency thereof. The views and opinions of authors expressed herein do not necessarily state or reflect those of the United States Government or any agency thereof. 


\section{DISCLAIMER}

Portions of this document may be illegible in electronic image products. Images are produced from the best available original document. 


\section{Summary}

In 1999, soil gas samples for helium-3 measurements were collected at two locations on the Hanford Site. Eight soil gas sampling points ranging in depth from 1.5 to $9.8 \mathrm{~m}$ ( 4.9 to $32 \mathrm{ft})$ below ground surface (bgs) in two clusters were installed adjacent to well 699-41-1, south of the Hanford Townsite. Fifteen soil gas sampling points, ranging in depth from 2.1 to $3.2 \mathrm{~m} \mathrm{(7} \mathrm{to} 10.4 \mathrm{ft}) \mathrm{bgs}$, were installed to the north and east of the $100 \mathrm{KE}$ Reactor. Gas phase soil moisture samples were collected using silica gel traps from all eight sampling locations adjacent to well 699-41-1 and eight locations at the $100 \mathrm{~K}$ Area.

No detectable tritium $(<240 \mathrm{pCi} / \mathrm{L})$ was found in the soil moisture samples from either the Hanford Townsite or $100 \mathrm{~K}$ Area sampling points. This suggests that tritiated moisture from groundwater is not migrating upward to the sampling points and there are no large vadose zone sources of tritium at either location. Helium-3 analyses of the soil gas samples showed significant enrichments relative to ambient air helium-3 concentrations with a depth dependence consistent with a groundwater source from decay of tritium. Helium-3/helium-4 ratios (normalized to the abundances in ambient air) at the Hanford Townsite

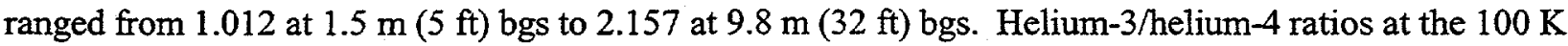
Area ranged from 0.972 to 1.131 . Based on results from the $100 \mathrm{~K}$ Area, we believe that a major tritium plume does not lie within that study area. The data also suggest there may be a tritium groundwater plume or a source of helium-3 to the southeast of the study area. We recommend that the study be continued by placing additional soil gas sampling points along the perimeter road to the west and to the south of the initial study area. 


\section{Acknowledgments}

We would like to acknowledge the help of $\mathrm{CH}_{2} \mathrm{M}$ Hill staff for their assistance in installing the soil gas sampling points. Special thanks goes to James (Mike) Faurote, David Weekes, and John Auten. 


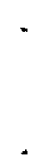




\section{Contents}

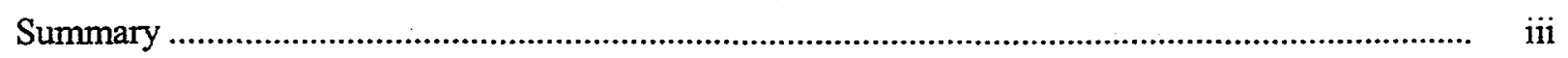

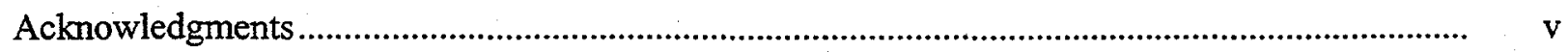

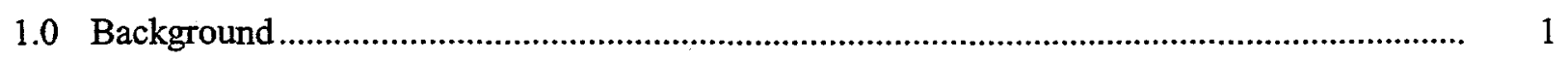

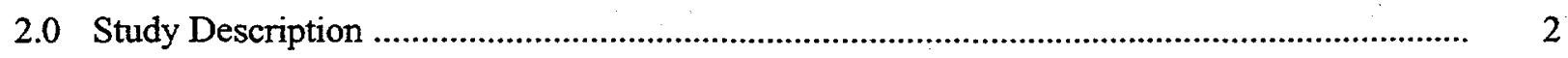

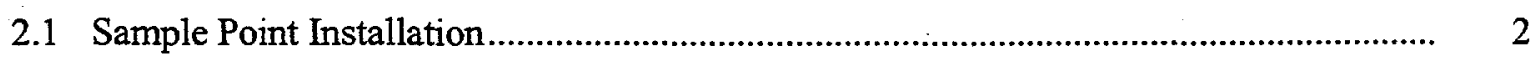

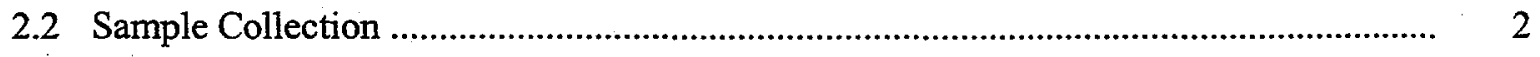

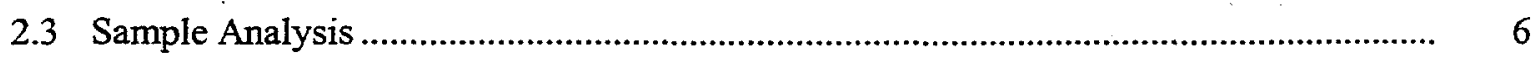

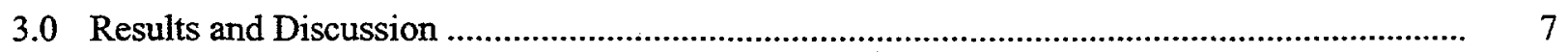

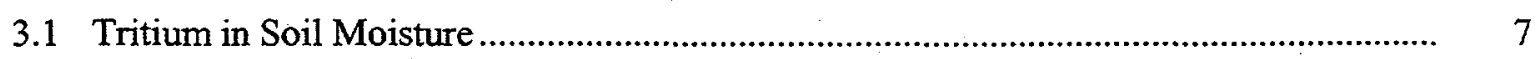

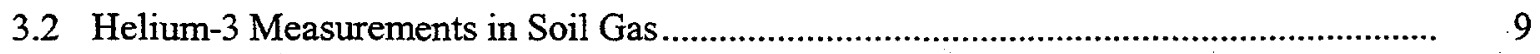

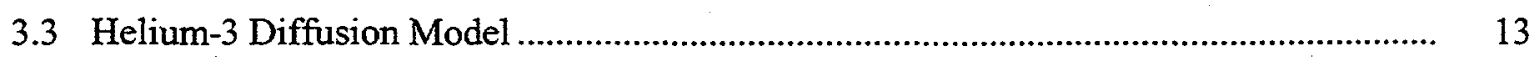

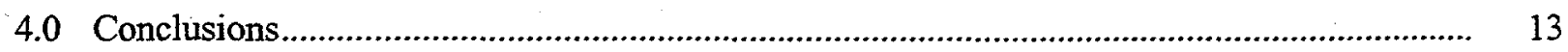

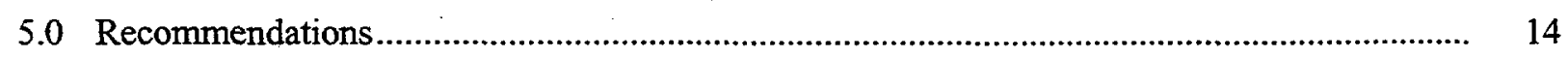

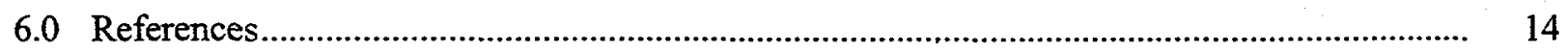




\section{Figures}

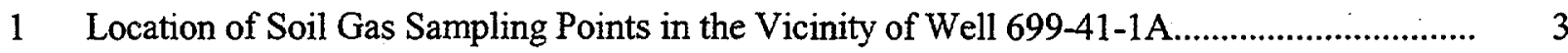

2 Locations of Soil Gas Sampling Points at $100 \mathrm{~K}$ Area ........................................................

3 Schematic Diagram of the Soil Gas Sampling System Used for Collection of Soil Moisture and Soil Gas Samples.

4 Comparison of Helium-3/Helium-4 Ratios for all Samples Collected at 699-41-1 Soil Gas Sampling Clusters Near Hanford Townsite

5 Comparison of Helium-3/Helium-4 Ratios in Before and After 24 Hour Samples at SG-1 and SG-2 Soil Gas Clusters Near Well 699-41-1.

6 Comparison of Helium-3/Helium-4 Ratios at Soil Gas Sampling Locations in the $100 \mathrm{~K}$ Area

\section{Tables}

1 Helium-3 and Tritium Results from Soil Gas Samples from the Hanford Townsite.

2 Helium-3 and Tritium Results from Soil Gas Samples from the $100 \mathrm{~K}$ East Area. 


\subsection{Background}

This study measured helium-3 and tritium concentrations in soil gas samples to detect and delineate groundwater tritium plumes. This approach is a modification of a successful technique developed in the late 1960 s used in age-dating deep ocean water as part of the GEOSECS ocean monitoring program. The approach was applied to shallow aquifers in the late 1980s by Poreda (1988) and Schlosser et al. (1988). All these studies were based on the presence of tritium, which decays to a stable, inert isotope, helium-3, i.e.:

$$
{ }^{3} \mathrm{H} \rightarrow{ }^{3} \mathrm{He}+\beta^{-} \mathrm{t}_{1 / 2}=12.32 \mathrm{yr}
$$

When tritiated water is released from a source into the subsurface environment and migrates downward to mix with groundwater, its daughter isotope, helium-3, begins to build up in the vadose zone and groundwater at the rate of tritium decay. The helium-3 then diffuses away from the source and toward the surface. Throughout this process, helium- 3 acts as a non-reactive tracer moving through the vadose zone. By contrast, tritium, as tritiated water in soil gas, is a somewhat reactive tracer, exchanging with water adsorbed on the surface of sediment in the vadose zone. Tritium is thus retarded, to some degree, in its movement through the vadose zone.

Based on their different mobility in the vadose zone environment, this study investigated the usefulness of using tritium in gas phase soil moisture and helium-3 in soil gas as tools for measuring tritium groundwater concentrations with near surface sampling techniques. In order to properly utilize this novel approach, a basic understanding of the behavior of tritiated soil moisture and helium-3 in the subsurface environment is needed. Critical issues which were evaluated in this study included

- What is the best method for collection of representative samples of tritiated soil moisture and helium-3 in soil gas?

- What are the concentrations of tritium in soil moisture and helium-3 in soil gas, which can be attributed only to a groundwater source of tritium?

- What is the relationship between tritium and helium-3 concentrations in the vadose zone?

- Is this method capable of estimating concentrations of tritium in the groundwater?

- Is this method capable of identifying vadose zone sources of tritium?

- What are the limits of this methodology? If this technique, using either tritiated soil moisture or helium-3, can accurately estimate tritium groundwater concentration, it will be used to identify the location of the highest tritium concentrations in the groundwater at $100 \mathrm{~K}$ study area. This information will help delineate the extent of the tritium plume from the $100 \mathrm{KE}$ Reactor area toward the Columbia River, and may be helpful for recommending optimal monitoring well location(s). 


\subsection{Study Description}

Twenty-four soil gas-sampling points were installed during the course of this study. Eight sampling points were installed in the vicinity of well 699-41-1, south of the Hanford Townsite (Figure 1). Soil gas clusters SG-1 and SG-2 were installed approximately 12.2 and $48.8 \mathrm{~m}$ (40 and $160 \mathrm{ft}$ ) to the north of well 699-41-1. Depth of completions of the four points associated with cluster SG-1 were: $1.5,3,6$, and $9.8 \mathrm{~m}(5,9.75,19.5$, and $32 \mathrm{ft}) \mathrm{bgs}$ or $19,17.5,14.5$, and $10.7 \mathrm{~m}(62.05,57.30,47.55$, and $35.05 \mathrm{ft})$ above groundwater. Depths of completion of the four points associated with cluster SG-2 were 1.5, 2.7, 5.3, and $8 \mathrm{~m}(4.9,8.9,17.5$, and $26.4 \mathrm{ft})$ bgs or $19,17.7,15$, and $12.4 \mathrm{~m}(62.15,58.15,49.55$, and $40.65 \mathrm{ft})$ above groundwater. Sixteen soil gas-sampling points were installed in the $100 \mathrm{~K}$ Area northeast of the $100 \mathrm{KE}$ Reactor complex generally in the downgradient direction (Figure 2). Depth of installation of the sampling points ranged from 2.1 to $3.2 \mathrm{~m}$ ( 7 to $10.4 \mathrm{ft}$ ) bgs.

\subsection{Sample Point Installation}

Soil gas sampling points were installed using a truck mounted Geoprobe ${ }^{\mathrm{TM}}$ Model 5400 system equipped with a 3.2-cm- (1.25-in.-) diameter probe and a detachable steel tip. When the tip reached the desired depth, a 20.3-cm- (8-in.-) long sampling point of fine mesh stainless steel was strung down the center of the push rod. The sampling point was connected to the surface with a $0.6 \mathrm{~cm}(1 / 4 \mathrm{in}$.) outerdiameter by $0.2 \mathrm{~cm}(3 / 32 \mathrm{in}$.) inner-diameter polyethylene tube. The rod assembly was withdrawn $15.2 \mathrm{~cm}$ (6 in.) to release the steel tip and allow the sampling point to extend into the void space just below the push rod. Approximately $250 \mathrm{ml}$ of 20 to $40 \mathrm{mesh}$, washed silica sand was added around the sampling point through the center of the push rod. The push rod was removed and the hole was allowed to collapse around the polyethylene tube. Approximately $250 \mathrm{ml}$ of granular bentonite was then added through the center of the push rod 0.6 to $0.9 \mathrm{~m}$ ( 2 to $3 \mathrm{ft}$ ) bgs at all the Hanford Townsite sampling points. The bentonite was not hydrated to prevent introduction of extraneous moisture near the sampling point. No bentonite was used for the soil gas sampling points at the $100 \mathrm{~K}$ Area. To complete those sampling points, a cement cap was poured around the sampling tube at the ground surface. Each sampling location was allowed to equilibrate for at least 24 hours and up to several weeks before soil gas samples were collected.

\subsection{Sample Collection}

All samples were collected with the aid of a Thomas flexible diaphragm pump Model 107CA14. Power to the pumps was supplied with a portable generator.

Soil moisture samples, using silica gel traps, were collected at all sampling points during the first sampling event adjacent to well 699-41-1 near the Hanford Townsite and at alternate locations at $100 \mathrm{~K}$ Area. The sampling system used to collect tritiated moisture was a modification of the system used to collect tritium in ambient air at the Hanford Site (Lodge 1989) for the Hanford Surface Environmental Surveillance Program (Figure 3). The modified system used only a single 18-cm- (7-in.-) long silica gel column, a flow rate of $1 \mathrm{~L}(0.026 \mathrm{gal})$ per minute, and a collection period of approximately 24 hours. The 


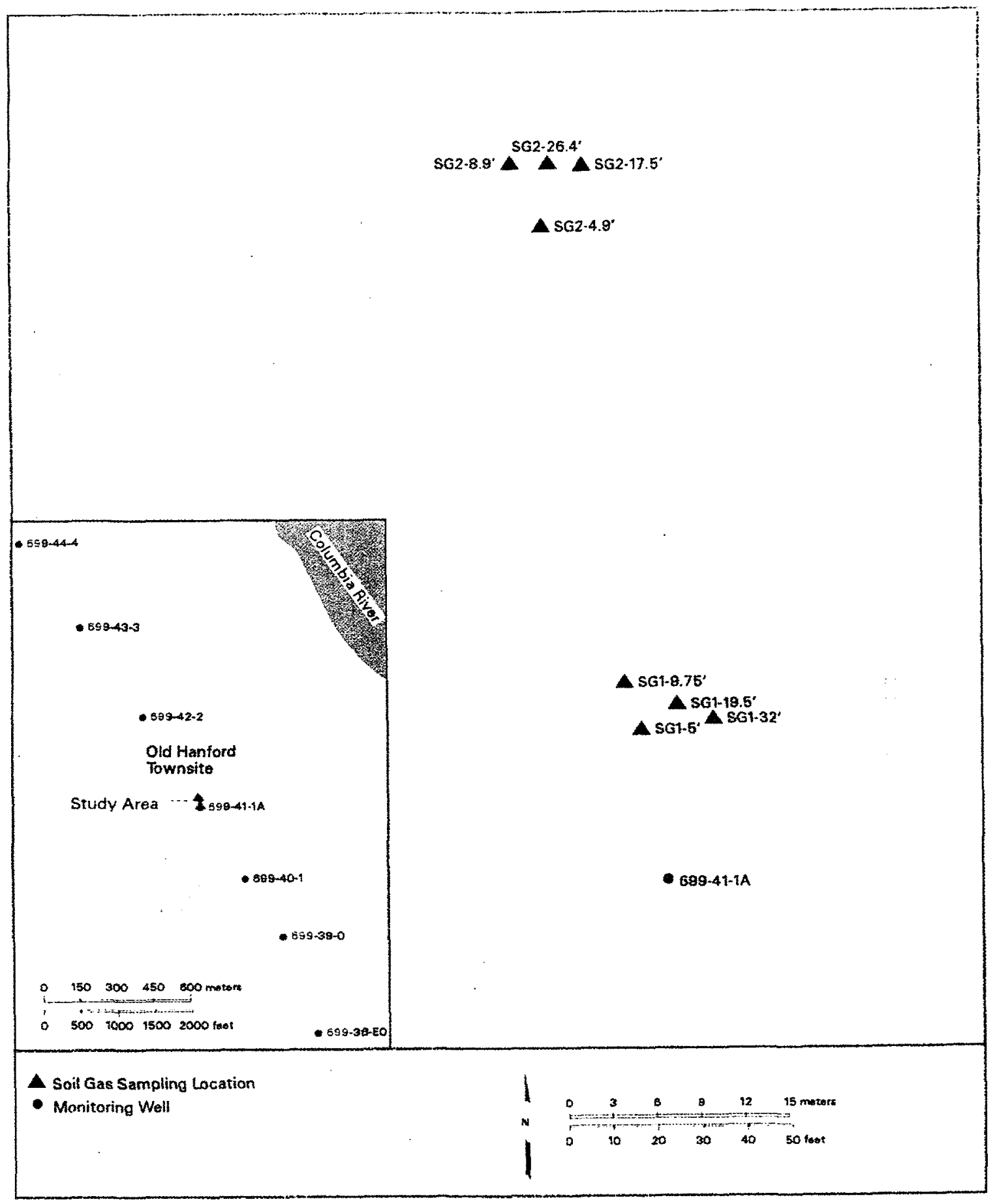

Figure 1. Lỏcation of Soil Gas Sampling Points in the Vicinity of Well 699-41-1A 


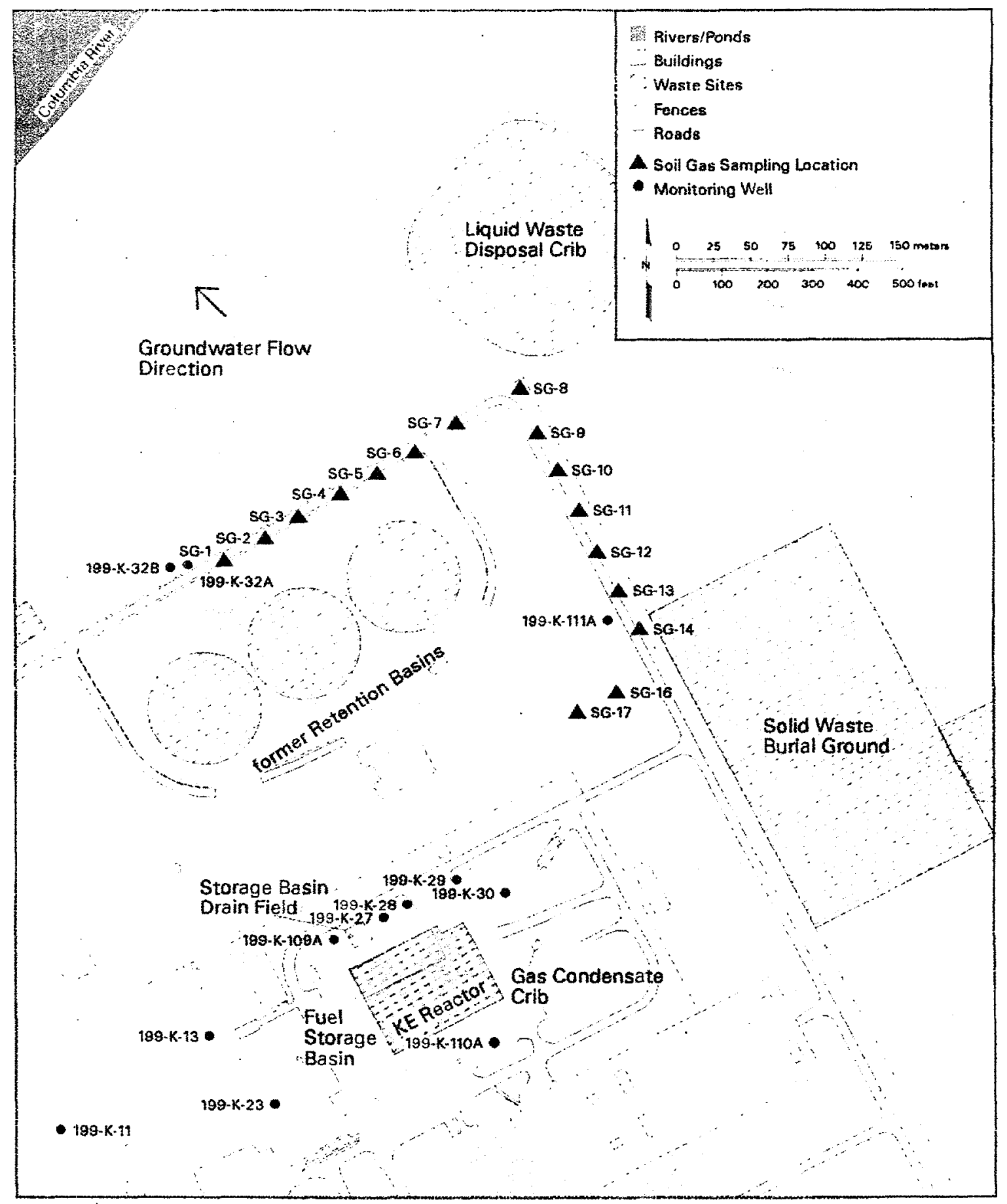

Figure 2. Locations of Soil Gas Sampling Points at $100 \mathrm{~K}$ Area 


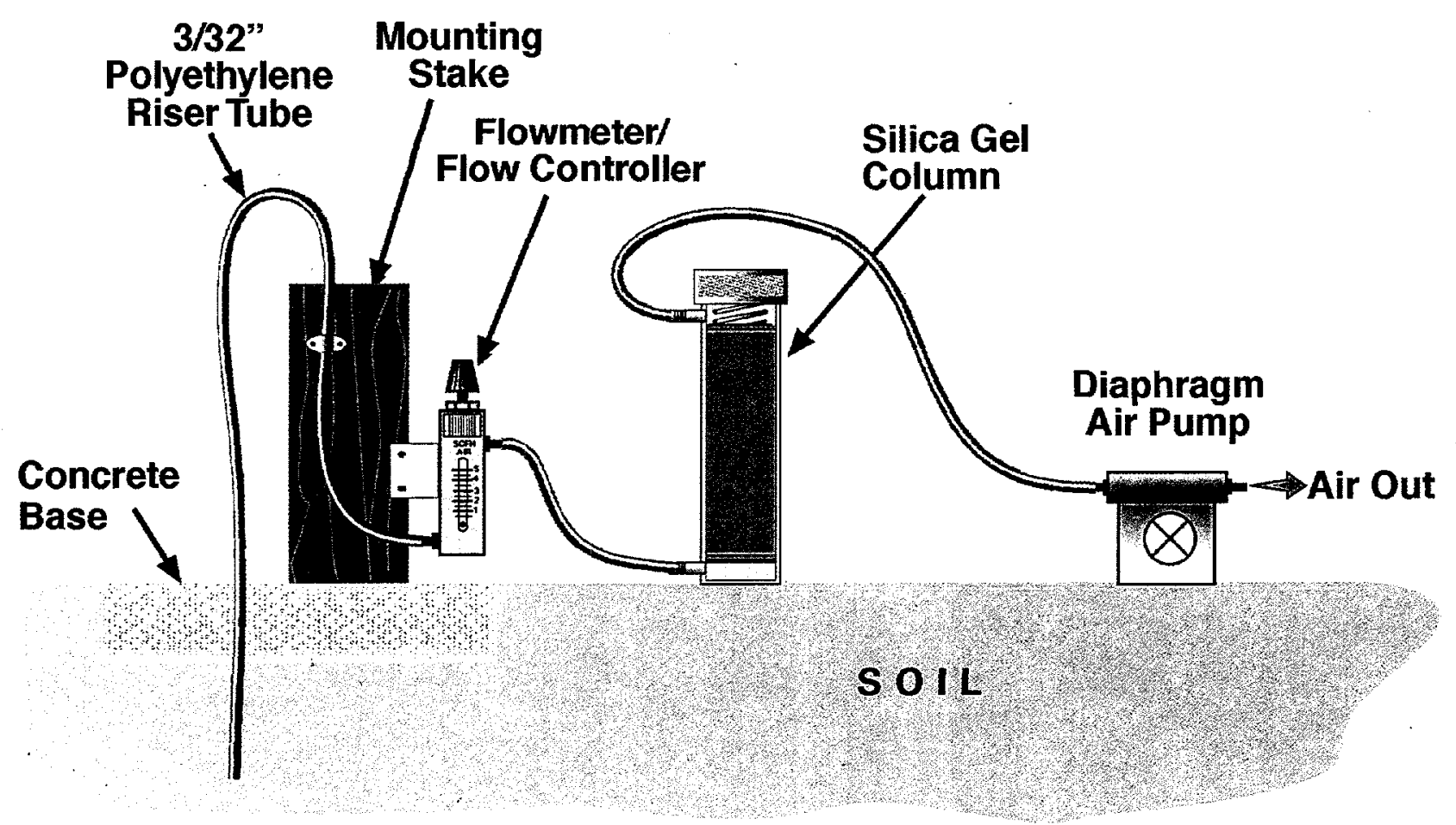

G99120048.1

Figure 3. Schematic Diagram of the Soil Gas Sampling System Used for Collection of Soil Moisture and Soil Gas Samples

system was configured in the following manner. The polyethylene riser tube from the soil gas sampling point was connected to the bottom of the flow controlling rotometer, through the base of the silica gel trap, out the top of the silica gel trap, then into the vacuum side of the pump. The pump was activated and the flow was allowed to equilibrate for 5 minutes or more. After the equilibration period, a Kurz Instruments ${ }^{\mathrm{TM}}$ mass flow meter was place in the flow stream between the polyethylene raiser tube and the bottom of the rotometer. The initial flow was adjusted to $1 \mathrm{~L}(0.026 \mathrm{gal})$ per minute. At the end of the sampling period, the final flow was recorded. The initial and final flows were averaged and the total flow calculated.

Pressurized bomb samples were collected for helium-3 analysis from each sampling location at the two sampling clusters adjacent to well 699-41-1 south of the Hanford Townsite and at the $100 \mathrm{~K}$ Area. The sampling bombs were $30-\mathrm{ml}$ stainless steel cylinders with one end sealed with a pipe plug and a high vacuum needle valve. A $0.6 \mathrm{~cm}$ (1/4 in.) Swagelok ${ }^{\mathrm{TM}}$ fitting was at the other end of the sampling bomb. Each bomb was evacuated to less than 5 torr before sampling. Two different sampling configurations were used to collect helium-3 samples. For the initial sampling at the Hanford Townsite, a silica gel trap was placed in the soil gas stream to quantitatively collect all soil moisture. The sampling system configuration was identical to that described above for the silica gel sampling of soil moisture. The soil gas sampling point was allowed to purge at $1 \mathrm{~L}(0.026 \mathrm{gal})$ per minute for a minimum of 5 minutes. At the end of the purging period, a hose was connected to the pressure side of the pump, and the bomb was 
pressurized to the maximum pressure of the pump. In a similar manner, a second set of bomb samples were collected at the end of the 24-hour silica gel collection. During subsequent sampling at the Hanford Townsite SG-1 sampling cluster, silica gel was not used because detectable tritium had not been observed in the soil moisture from previous measurements. In this situation, a rotometer and pump were connected in series to the riser tube from the soil gas sampling point. Flow was adjusted to $1 \mathrm{~L}(0.026 \mathrm{gal})$ per minute and allowed to purge for a minimum of 60 minutes. At the end of the purge period, the bomb was connected to the pressure side of the pump and allowed to pressurize to the pump's maximum pressure. Because silica gel traps were installed only at alternate sampling locations at $100 \mathrm{~K}$ Area, bomb samples were collected either through silica gel traps or without silica gel. All sites were purged for approximately 60 minutes before collection.

\subsection{Sample Analysis}

After collection, silica gel traps were sent for analysis to Quanterra Environment Services laboratory in Richland, Washington. The soil moisture was thermally desorbed from the silica gel adsorbent and collected on a cold trap. The tritium content of the desorbed water, was determined by liquid scintillation counting. The detection limit, using a $10-\mathrm{ml}$ sample aliquot, was estimated to be $240 \mathrm{pCi} / \mathrm{L}$.

After collection, helium soil gas samples were sent to the University of Rochester for helium-3 analysis. Upon receipt of the samples, a $0.5 \mathrm{ml}$ aliquot of air was processed through a high vacuum line constructed of stainless steel and Corning-1724 glass to minimize helium diffusion. After removal of water vapor and carbon dioxide at $-90^{\circ} \mathrm{C}\left(-194^{\circ} \mathrm{F}\right)$ and $-195^{\circ} \mathrm{C}\left(-383^{\circ} \mathrm{F}\right)$, respectively, the amount of noncondensable gas (argon, helium, methane, neon, nitrogen, and oxygen) was measured using a calibrated volume and a capacitance manometer. Gas ratios (argon, methane, and nitrogen) were analyzed on a Dycor Quadrupole mass spectrometer fitted with a variable leak valve. The results are combined with the capacitance manometer measurement to obtain gas concentrations $( \pm 2 \%)$. Prior to helium isotope analyses, nitrogen and oxygen were removed by reaction with zirconium-aluminum alloy (SAES ST707), argon and neon were adsorbed on activated charcoal at $77^{\circ} \mathrm{K}$ and at $40^{\circ} \mathrm{K}$, respectively. SAES-ST-101 Getters (one in the inlet line and two in the mass spectrometer) reduced the $\mathrm{HD}^{+}$background to $\sim 1,000$ ions per second.

Helium isotope ratios and concentrations were analyzed on a VG 5400 Rare Gas Mass Spectrometer fitted with a Faraday cup (resolution of 200) and a Johnston electron multiplier (resolution of 600) for sequential analyses of the helium-4 (F-cup) and helium-3 (multiplier) beams. On the axial collector (resolution of 600 ), ${ }^{3} \mathrm{He}^{+}$was completely separated from $\mathrm{HD}^{+}$with a baseline separation of $<2 \%$ of the $\mathrm{HD}^{+}$peak. The contribution of $\mathrm{HD}^{+}$to the helium-3 peak was $<0.1$ ion per second at 1,000 ions per second of $\mathrm{HD}^{+}$. For $2.0 \mathrm{ml}$ of helium with an air ratio sensitivity of $2 \times 10^{-4} \mathrm{Amps} / \mathrm{torr}$, the helium-3 signal averaged 2,500 ions per second with a background signal of $\sim 15 \mathrm{cps}$, due to either scattered helium- 4 ions or the formation of helium- 4 ions at lower voltage potentials within the source of the mass spectrometer. All helium-3/ helium- 4 ratios were reported relative to the atmospheric ratio $\left(R_{A}\right)$, using air helium as the absolute standard. Errors in the helium-3/helium-4 ratios result from the precision of the sample measurement $( \pm 0.2 \%)$ and variation in the ratio measurement in air $( \pm 0.2 \%)$ and give a total error 
of $\pm 0.3 \%$ at $2 \sigma$ for the reported helium isotope value. Helium concentrations were derived from comparison of the total sample to a standard of known size. The value, as measured by peak height comparison, was accurate to $\pm 1 \%(2 \sigma)$.

During the analysis, three bombs from the initial sampling in the vicinity of well 699-41-1 were found to have leaked to ambient pressure; consequently, the data was considered to be suspect and rejected. Suspect samples included before and after samples taken from SG1-32 and the after sample from SG1-19.5. Because of this problem, soil gas cluster SG-1 was subsequently resampled at a later date. One sample, SG1-5, from the second sampling, was found to have also leaked to ambient pressure. Two samples from the $100 \mathrm{~K}$ Area sampling, $100 \mathrm{~K}-\mathrm{SG} 2$ and $100 \mathrm{~K}-\mathrm{SG} 4$, also leaked to ambient pressure and the data was rejected.

\subsection{Results and Discussion}

Proof-of-principal testing was conducted at the Hanford Townsite where there is a large tritium plume with little variability in tritium concentrations over short distances. There are no known vadose zone sources of tritium in this area that could possibly effect the tritium concentration in soil gas soil moisture, or the helium- 3 concentration in soil gas. Furthermore, there was a concern that the proximity to a groundwater monitoring well could further effect the tritium/helium-3 equilibrium because of air exchange caused by atmospheric pumping through an open screen interval above the water table. This condition existed at the $100 \mathrm{~K}$ study area for wells $199-\mathrm{K}-111 \mathrm{~A}$ and 199-K $-32 \mathrm{~A}$. These wells are located directly adjacent to several soil gas sampling points.

\subsection{Tritium in Soil Moisture}

The use of tritium measurements in soil moisture as an indicator of tritium concentration in groundwater was first tested in the vicinity of well 699-41-1, just south of the Hanford Townsite. Table 1 contains the results of tritium analysis on soil moisture collected in the vicinity of well 699-41-1. Data from the $100 \mathrm{~K}$ Area are listed in Table 2. Tritium concentrations in soil moisture at $100 \mathrm{~K}$ Area and in the vicinity of well 699-41-1 were found to be all less than the detection limit of the analytical method (minimum detection limit $=240 \mathrm{pCi} / \mathrm{L}$ ).

These results were unexpected because the tritium concentration in groundwater at 699-41-1 was measured at $117,000 \mathrm{pCi} / \mathrm{L}$ in late July 1999 , shortly after soil gas sampling. The tritium plume in this area is quite extensive with little variability over short distances. This observation suggests that tritiated moisture from groundwater is not migrating upward to the sampling points at the sampling locations. These data also indicate that the soil moisture collected can be attributed to recharge of natural precipitation into the vadose zone around the sampling locations. This hypothesis agrees with work done by Faye et al. (1997), which estimated recharge at $10 \mathrm{~cm}$ (3.9 in.) per year. The concentration of tritium in natural precipitation normally ranges from 50 to $80 \mathrm{pCi} / \mathrm{L}$, well below the detection limit of the analytical 
Table 1. Helium-3 and Tritium Results from Soil Gas Samples from the Hanford Townsite

\begin{tabular}{|c|c|c|c|c|c|}
\hline Sample ID & $\begin{array}{l}\text { Depth bgs } \\
\text { m (ft) }\end{array}$ & $\begin{array}{c}\text { Sample } \\
\text { Date }\end{array}$ & Tritium $(\mathrm{pCi} / \mathcal{L})$ & $\begin{array}{c}{ }^{3} \mathrm{He} /{ }^{4} \mathrm{He} \\
\left(\mathrm{R} / \mathrm{R}_{\mathrm{a}}\right)\end{array}$ & Comment \\
\hline SG1-5 & $1.5 \quad(5.0)$ & 7/19/99 & $<240$ & 0.997 & \\
\hline SG1-9.75 & $3.0 \quad(9.8)$ & 7/19/99 & $<240$ & 1.136 & \\
\hline SG1-19.5 & $6.0 \quad(19.5)$ & 7/19/99 & $<240$ & 1.166 & \\
\hline SG1-32 & $9.8 \quad(32.0)$ & $7 / 19 / 99$ & $<240$ & 1.169 & Suspect Data* \\
\hline SG2-4.9 & $1.5 \quad(4.9)$ & $7 / 19 / 99$ & $<240$ & 1.007 & \\
\hline SG2-8.9 & $2.7 \quad(8.9)$ & $7 / 19 / 99$ & $<240$ & 1.033 & ' \\
\hline SG2-17.5 & $5.3 \quad(17.5)$ & $7 / 19 / 99$ & $<240$ & 1.177 & \\
\hline SG2-26.4 & $8.0(26.4)$ & $7 / 19 / 99$ & $<240$ & 1.343 & \\
\hline Ambient Air & 0 & 7/19/99 & $<240$ & 0.985 & \\
\hline SG1-5 & $1.5 \quad(5.0)$ & $7 / 20 / 99$ & $<240$ & 1.023 & \\
\hline SG1-9.75 & $3.0 \quad(9.8)$ & $7 / 20 / 99$ & $<240$ & 1.181 & \\
\hline SG1-19.5 & $6.0(19.5)$ & $7 / 20 / 99$ & $<240$ & 1.133 & Suspect Data* \\
\hline SG1-32 & $9.8 \quad(32.0)$ & $7 / 20 / 99$ & $<240$ & 1.235 & Suspect Data* \\
\hline SG2-4.9 & $1.5 \quad(4.9)$ & 7/20/99 & $<240$ & 1.030 & \\
\hline SG2-8.9 & $2.7 \quad(8.9)$ & 7/20/99 & $<240$ & 1.035 & \\
\hline SG2-17.5 & $5.3 \quad(17.5)$ & 7/20/99 & $<240$ & 1.228 & \\
\hline SG2-26.4 & $8.0 \quad(26.4)$ & 7/20/99 & $<240$ & 1.471 & \\
\hline SG1-5 & $1.5 \quad(5.0)$ & 9/3/99 & $<240$ & 1.016 & Suspect Data* \\
\hline SG1-9.75 & $3.0 \quad(9.8)$ & 9/3/99 & $<240$ & 1.302 & \\
\hline SG1-19.5 & $6.0 \quad(19.5)$ & 9/3/99 & $<240$ & 1.893 & \\
\hline SG1-32 & $9.8 \quad(32.0)$ & $9 / 3 / 99$ & $<240$ & 2.159 & \\
\hline
\end{tabular}

method used to measure tritium in soil moisture. These results strongly suggest that collecting samples of soil moisture will not be successful for estimating tritium groundwater concentrations because the movement of moisture would be downward from natural precipitation, not upward from the groundwater surface.

Because no detectable tritium was found in soil moisture samples collected in the vicinity of well 699-41-1, only alternate soil gas sampling locations at the $100 \mathrm{~K}$ Area were sampled for tritium in gas phase soil moisture. The samples collected were used only to verify the presence or absence of vadose zone sources of tritium at or near the sampling locations. If a vadose zone source of tritium had been present in the vicinity of the soil gas sampling location, elevated tritium concentrations would have been observed in the collected moisture samples. If present, elevated tritium concentrations associated with a 
Table 2. Helium-3 and Tritium Results from Soil Gas Samples from the $100 \mathrm{~K}$ East Area

\begin{tabular}{|c|c|c|c|c|c|}
\hline Sample ID & $\begin{array}{l}\text { Depth bgs } \\
\text { m (ft) }\end{array}$ & $\begin{array}{c}\text { Sample } \\
\text { Date }\end{array}$ & Tritium (pCi/L) & $\begin{array}{c}{ }^{3} \mathrm{He} /{ }^{4} \mathrm{He} \\
\left(\mathrm{R} / \mathrm{R}_{\mathrm{a}}\right)\end{array}$ & Comment \\
\hline $100 \mathrm{~K}-\mathrm{SG} 1$ & $2.1 \quad(7.0)$ & 9/2/99 & $<240$ & 1.003 & \\
\hline $100 \mathrm{~K}-\mathrm{SG} 2$ & $3.0(10.0)$ & $9 / 2 / 99$ & NS & 0.962 & Suspect Data* \\
\hline $100 \mathrm{~K}-\mathrm{SG} 3$ & $3.0(10.2)$ & $9 / 2 / 99$ & $<240$ & 0.994 & \\
\hline $100 \mathrm{~K}-\mathrm{SG} 4$ & $2.9 \quad(9.5)$ & $9 / 2 / 99$ & NS & 0.990 & Suspect Data* \\
\hline $100 \mathrm{~K}-\mathrm{SG} 5$ & $3.2(10.4)$ & $9 / 2 / 99$ & $<240$ & 1.004 & \\
\hline $100 \mathrm{~K}-\mathrm{SG} 6$ & $3.2(10.4)$ & $9 / 2 / 99$ & NS & 0.981 & \\
\hline $100 \mathrm{~K}-\mathrm{SG} 7$ & $2.9 \quad(9.5)$ & $9 / 2 / 99$ & $<240$ & 0.985 & \\
\hline 100K-SG8 & $3.1 \quad(10.1)$ & 9/2/99 & NS & 9.730 & \\
\hline 100K-SG9 & $3.1 \quad(10.3)$ & $9 / 7 / 99$ & $<240$ & 0.984 & \\
\hline $100 \mathrm{~K}-\mathrm{SG} 10$ & $2.9 \quad(9.4)$ & 9/7/99 & $\mathrm{NS}$ & 0.992 & \\
\hline 100K-SG11 & $2.4 \quad(8.0)$ & 9/7/99 & $<240$ & 0.989 & \\
\hline 100K-SG12 & $3.1(10.1)$ & $9 / 7 / 99$ & NS & 1.012 & \\
\hline 100K-SG13 & $3.1 \quad(10.1)$ & $9 / 7 / 99$ & $<240$ & 1.026 & \\
\hline 100K-SG14 & $2.2 \quad(7.2)$ & $9 / 7 / 99$ & NS & 1.036 & \\
\hline 100K-SG16 & $2.8 \quad(9.3)$ & 9/7/99 & $<240$ & 1.132 & \\
\hline 100K-SG17 & $3.1(10.3)$ & $9 / 7 / 99$ & NS & 1.014 & \\
\hline
\end{tabular}

vadose zone source could be confused with an elevated tritium concentration in the groundwater below the sampling point. However, no elevated tritium was observed in any of the $100 \mathrm{~K}$ Area soil moisture samples at the $240-\mathrm{pCi} / \mathrm{L}$ detection limit.

\subsection{Helium-3 Measurements in Soil Gas}

Proof-of-concept for the use of helium-3 as an indicator of tritium concentration in groundwater was first tested in the vicinity of well 699-41-1, just south of the Hanford Townsite. The first cluster (SG-1) was placed within $15.2 \mathrm{~m}(50 \mathrm{ft})$ of the well. The second cluster (SG-2) was placed approximately $48.8 \mathrm{~m}$ $(160 \mathrm{ft}$ ) from the well. This spatial arrangement was used to study the effects of atmospheric pumping on the concentration of tritium in soil moisture and helium-3 in the soil gas through a well screened above the water table. The area investigated at the $100 \mathrm{~K}$ Area has two such wells in the vicinity of the soil gas sampling points, wells $199-\mathrm{K}-32 \mathrm{~A}$ and $199-\mathrm{K}-111 \mathrm{~A}$ where a portion of the screened interval is across the water table. Potentially, the well could provide a conduit for loss of tritiated soil moisture or helium from the soil column above the water table by atmospheric pumping. This would result in disequilibrium between tritium and helium-3 concentration in the soil gas. The placement of the second cluster $48.8 \mathrm{~m}$ $(160 \mathrm{ft}$ ) from the well was believed to minimize any potential effects of atmospheric pumping from the 
nearby well. However, the fact that no detectable tritium was found in the soil moisture, while enrichment of helium- 3 concentrations was observed at both clusters, suggests that there was a significant disequilibrium between the two species. We believe this disequilibrium was caused by the effects of precipitation moisture migrating downward rather than atmospheric pumping through an open screened interval in a well.

The helium-3 analyses of the soil gas samples from the Hanford Townsite (see Table 1) showed significant enrichment of helium-3 concentrations relative to ambient air (air is normalized to 1). An inverse relationship between helium-3 concentration and vertical distance from the source (groundwater) was also observed. Relative helium-3/helium-4 ratios at the Hanford Townsite location ranged from

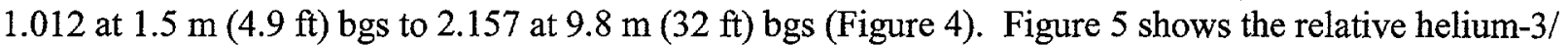
helium-4 ratios from samples taken at the beginning and at the end of the 24-hour-long sampling event in July. In all but one sample, the ratios at the end of the event are greater than at the beginning of the event. However, these increases were not considered significant and, therefore, it was concluded that helium-3 samples could be collected after minimal purging of the soil gas sampling point (e.g., 5 to 60 minutes of purging). The variability with time is even more pronounced by comparing the July and September SG-1 sampling events (see Figure 4). All the helium-3/helium-4 rations are significantly higher in September. The greatest difference is shown for the helium-3/helium-4 ratios from $6 \mathrm{~m}(19.5 \mathrm{ft})$. There was a $62 \%$ increased enrichment in helium-3 in the September sample relative to the earlier measurement. These temporal variations might be attributable to atmospheric pumping in the vadose zone due to fluctuations in atmospheric pressure. That is, higher atmospheric pressure may dilute the helium-3 in the vadose zone with low helium-3/helium-4 ratio atmospheric air. Conversely, during periods of low pressure the well would be outgassing soil vapor enriched in helium-3. This outgassing may result in enhanced diffusion

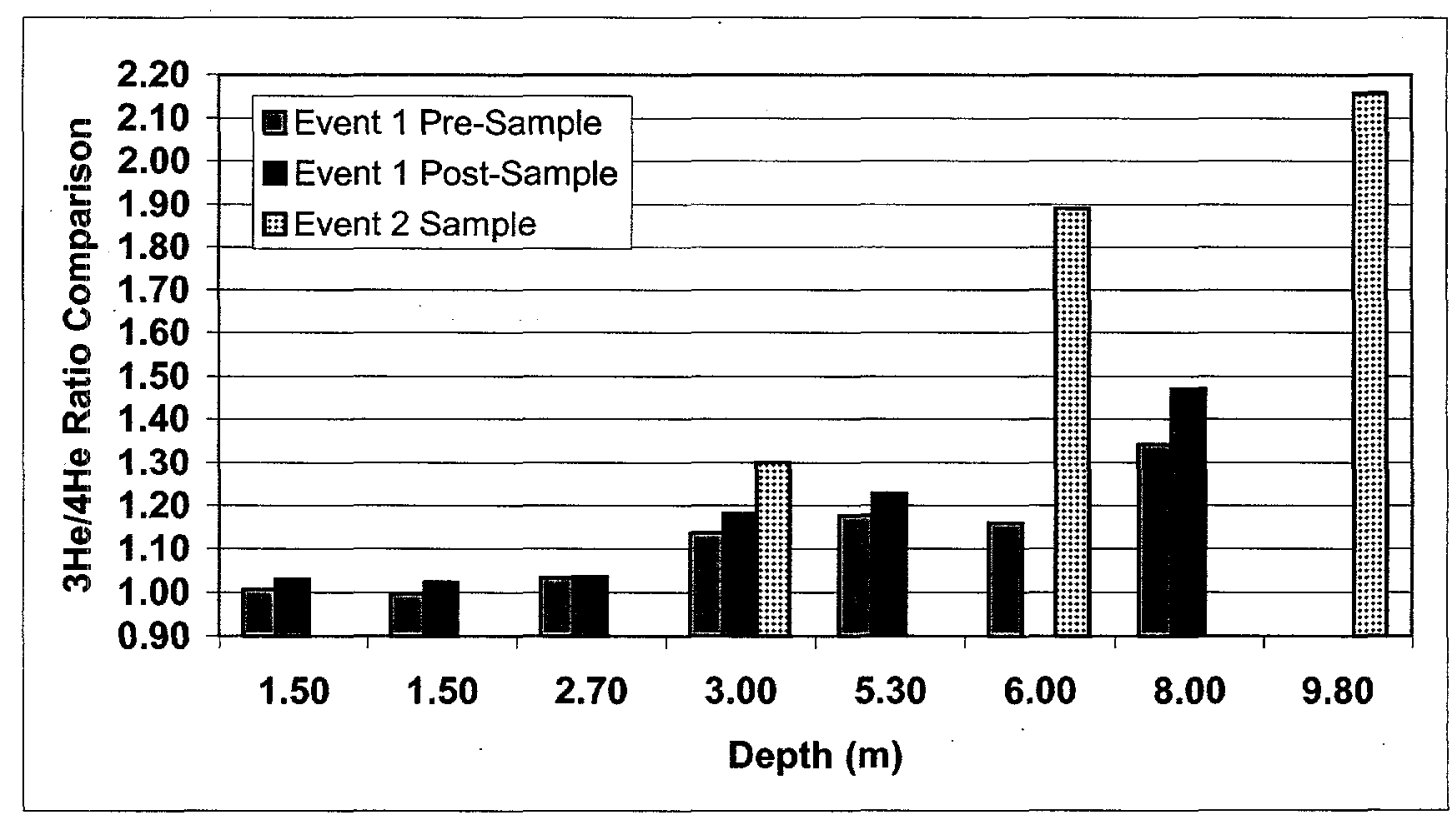

Figure 4. Comparison of Helium-3/Helium-4 Ratios for all Samples Collected at 699-41-1 Soil Gas Sampling Clusters Near Hanford Townsite 


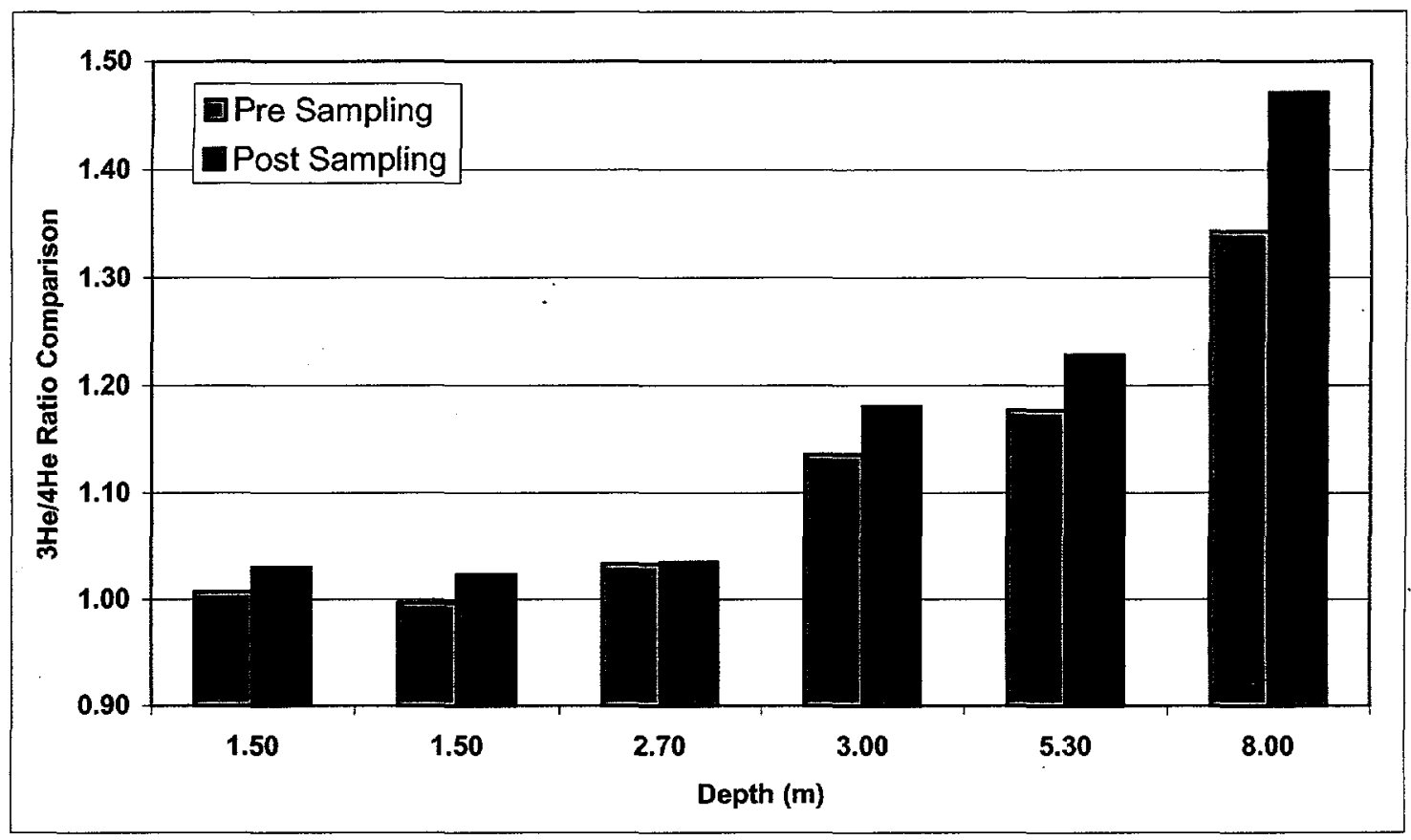

Figure 5. Comparison of Helium-3/Helium-4 Ratios in Before and After 24 Hour Samples at SG-1 and SG-2 Soil Gas Clusters Near Well 699-41-1

where soil gas is being drawn from a zone deeper in the vadose zone (closer to the groundwater source of helium-3) and more highly enriched in helium-3: Atmospheric pumping can occur at the soil surface, but this effect rapidly decreases as depth increases or through a well if an opened screen interval exists above the water table. At the time of soil gas sampling, there was approximately $0.3 \mathrm{~m}(1 \mathrm{ft})$ of screened interval open to the atmosphere in well 699-41-1A, directly adjacent to sampling clusters SG-1. Thus, atmospheric pumping may have affected the helium-3/helium-4 ratios at SG-1. However, because the SG-2 sampling points were not resampled in September, no direct comparison can be made between the two sites or the variability between the July and September sampling results at SG-2.

The helium- 3 results from all the sampling points at the $100 \mathrm{~K}$ Area suggest no tritium plume is located within the study area. Helium-3/helium-4 ratios in the soil gas samples collected in the $100 \mathrm{~K}$ Area ranged from 0.972 to 1.131 (Figure 6). The greatest helium-3 enrichment (sample point SG-16) is in the southeast part of the study area suggesting that there may be a tritium source around that location. Because there was no tritium found in the soil moisture in the immediate area of SG-16, helium-3 must be

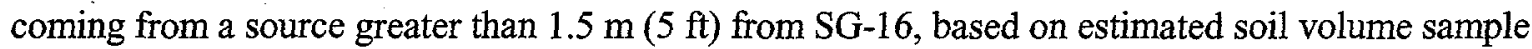
during tritium sampling. The source could possibly be a solid waste burial ground or one or more of several cribs east of the $100 \mathrm{KE}$ Reactor building. Alternatively, the source could be from the groundwater plume in the area. However, the groundwater monitoring well 199-K-111, located adjacent to several soil gas monitoring points at the southeast end of the study area, has no measurable tritium (minimum detection limit $<240 \mathrm{pCi} / \mathrm{L}$ ). This suggests that there is not a tritium groundwater plume within the study area. If a tritium plume exists, it could be located farther to the south of the study area. However, 


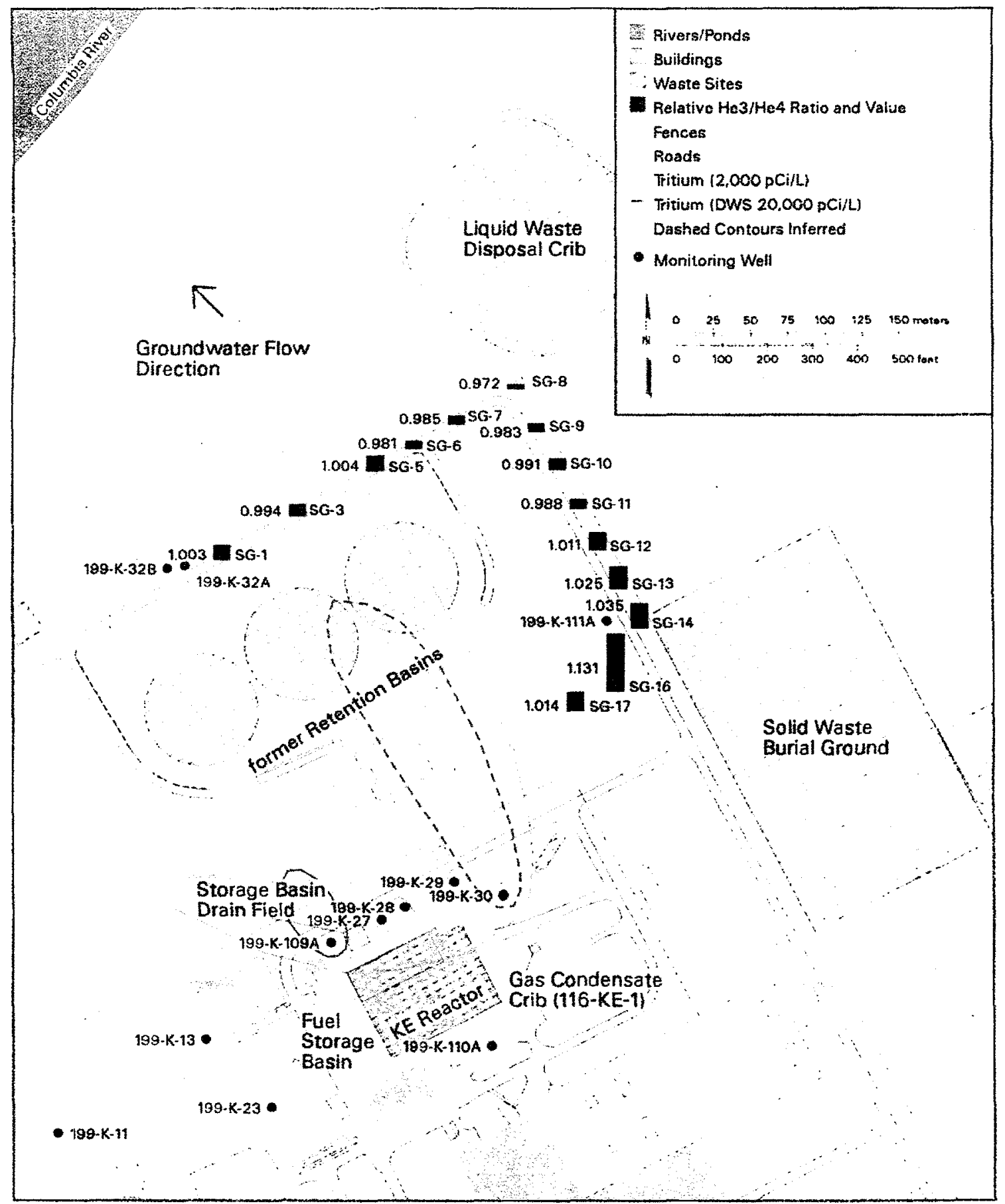

Figure 6. Comparison of Helium-3/Helium-4 Ratios at Soil Gas Sampling Locations in the $100 \mathrm{~K}$ Area 
this is unlikely because the groundwater flow direction is to the north. Further investigation is necessary to define and identify the source of helium-3 around the southeast corner of the study area.

\subsection{Helium-3 Diffusion Model}

To estimate an equilibrium concentration between tritium in groundwater and helium-3 directly above the groundwater with a known concentration of $136,000 \mathrm{pCi} / \mathrm{L}$, a simple $1-\mathrm{D}$ diffusion model was used to calculate the flux of helium-3 out of a stagnant pool of water. The model was run forward for 10 years to stabilize the release of helium-3. As long as the vertical velocity of the water is small $(<5 \mathrm{~cm}[2 \mathrm{in}$.] per year), the solutions for $\mathrm{V}(\mathrm{z})<5 \mathrm{~cm}(2 \mathrm{in}$.) per year are not significantly different from a $\mathrm{V}(\mathrm{z})=0$. We calculated a flux of helium-3 out of the tritiated water $\left(1 \times 10^{11}\right.$ atoms $/ \mathrm{m}^{2} /$ day) that enters the base of the unsaturated zone. The measured base of the unsaturated zone contains about $7 \times 10^{13}$ atoms of ${ }^{3} \mathrm{He} / \mathrm{m}^{3}$ of soil (relative to an atmospheric concentration of $5.6 \times 10^{13}$ atoms $/ \mathrm{m}^{3}$ of soil at $35 \%$ porosity) or an excess of helium-3 of about $25 \%$. Clearly, the results from this 1-D diffusion model are conservative. Maximum enrichment values in samples collected some distance above the groundwater surface in the area around well 699-41-1 were observed to be significantly higher than expected even for the limiting case of the groundwater surface-vadose zone interface. The fact that the model did not accurately predict the amount of helium- 3 observed in the vadose zone indicates that there may be enhanced transfer (atmospheric pumping) of helium-3 from deeper parts of the system. However, a more probable explanation is simply that the thickness of the tritium ladened groundwater is significantly greater then the model assumes. Because the study area was located in a region of the tritium plume distant from the source, the plume thickness is expected to be quite large as a result of vertical dispersion; however, measurements of the vertical distribution of tritium in the groundwater at that location have not been made. In order to obtain more accurate estimates of helium-3 enrichment in the vadose zone, it will be necessary to have an accurate determination of the thickness of the tritium ladened groundwater at that location.

\subsection{Conclusions}

Measurements of tritium in soil moisture do not appear to be useful for delineating tritium groundwater plumes or estimating concentrations of tritium in groundwater. The major source of moisture in the vadose zone at the two investigated sites appears to be natural precipitation and not upward migration of moisture from groundwater into the vadose zone. However, analysis of vadose zone moisture samples for tritium may be helpful in identifying vadose zone sources of tritium near a specific sampling site. Analyses of soil gas from samples collected at the Hanford Townsite area show significant enrichment in helium-3. The observed enrichment is due to the decay of tritium in the groundwater beneath the site since there are no vadose zone tritium sources in the vicinity. The amount of enrichment appears to vary with time, most likely due to atmospheric pumping. Nevertheless, helium-3 can be a useful tracer for either vadose zone or groundwater sources of tritium. Because atmospheric pumping can affect the results of helium-3 concentrations in the soil gas, the entire suite of samples should be collected in as short a time span as possible. This is particularly important if samples are to be collected deep in the 
vadose zone near a groundwater well screened across the water table. Helium-3 results from samples from the $100 \mathrm{~K}$ Area do not suggest the presence of tritiated groundwater beneath the study area. Based on the relative enrichment factors for helium-3, there may be a groundwater or vadose zone source of tritium southeast of the study area. Potential sources include a groundwater tritium plume, the solid waste burial ground, the 116-KE-1 gas condensate crib east of the $100 \mathrm{KE}$ Reactor, or $100 \mathrm{KE}$ fuel storage basins.

\subsection{Recommendations}

Based on groundwater flow direction at the $100 \mathrm{~K}$ Area, we recommend that the study be continued by placing additional soil gas sampling points along the perimeter road to the northwest of the study area. This area may contain a narrow tritium groundwater plume where concentrations could exceed $1,000,000 \mathrm{pCi} / \mathrm{L}$. In addition, continuing the study along the perimeter road to the south may help identify vadose zone sources of tritium near the soil waste burial ground and/or cribs located near the $100 \mathrm{KE}$ Reactor facility, which may have received process water containing tritium exceeding $1,000,000 \mathrm{pCi} / \mathrm{L}$. These activities should be conducted before any additional wells specifically intended for delineation of the tritium plume(s) are installed along the riverside of the $100 \mathrm{~K}$ Area.

\subsection{References}

Faye, M. J., G. W. Gee, M. L. Rockhold, M. D. Freshley, and T. B. Walters. 1997. "Estimating

Recharge Rates for a Groundwater Model using a GIS." J. Environ. Quality 25:510-518.

Lodge, J. P., Jr. 1989. Methods of Air Sampling and Analysis. 3rd ed. Method 609A. Chelsea: Lewis Publishers, Inc.

Poreda, R. J., T. E. Cerling, and D. K. Salomon. 1988. "Tritium and Helium Isotopes as Hydrologic Tracers in a Shallow Unconfined Aquifer." Journal of Hydrology 103:1-9.

Schlosser, P., M. Stute, H. Där, C. Sonntag, and K. O. Munnich. 1988. Tritium/3 ${ }^{3}$ He Dating of Shallow Groundwater. Earth and Planetary Science Letters 89, 353. 


\section{Distribution}

No. of

\section{Copies}

\section{OFFSITE}

Robert Poreda

Department of Earth and Environmental Sciences

227 Hutchison Hall

University of Rochester

Rochester, NY 14627

Confederated Tribes of the Umatilla Indian Reservation

Environmental Planning/Rights Protection

P.O. Box 638

Pendleton, OR 97801

ATTN: W. Burke

R. A. Danielson

Washington State Department of Health

5508 Englewood Avenue

Yakima, WA 98908

M. K. Harmon

U.S. Department of Energy

Cloverleaf Building, EM-44

19901 Germantown Road

Germantown, MD 20874-1290

R. E. Jaquish

Washington State Department of Health

1232 Vintage Ave.

Richland, WA 99352

L. Seelatsee

Wanapum People

Grant County P.U.D.

30 "C" Street S.W.

P.O. Box 878

Ephrata, WA 98823
No. of

Copies

P. Sobotta

Nez Perce Tribe

Environmental Restoration/Waste

Management

P.O. Box 365

Lapwai, ID 83540-0365

State of Oregon Office of Energy

625 Marion Street N.E.

Salem, OR 97310

ATTN: D. Dunning

Confederated Tribes and Bands of the Yakama Nation

Environmental Restoration/Waste

Management

2808 Main Street

Union Gap, WA 98903

ATTN: W. Rigsby

\section{ONSITE}

\section{DOE Richland Operations Office}

M. J. Furman

A5-13

R. D. Hildebrand

A5-13

R. G. McLeod

$\mathrm{H} 0-12$

F. M. Roddy

A5-11

K. M. Thompson

A5-13

A. C. Tortoso

H0-12

Public Reading Room

$\mathrm{H} 2-53$

2 Bechtel Hanford, Inc.

B. H. Ford

$\mathrm{H} 0-21$

G. B. Mitchem

Distr.1 
No. of

Copies

3 CH2M Hill Hanford, Inc.

J. V. Borghese

H9-03

J. M. Faurote

H9-02

L. C. Swanson

$\mathrm{H} 9-02$

2 Fluor Hanford, Inc.

G. S. Hunacek, Jr.

$\mathrm{X} 3-79$

D. J. Watson

$\times 3-79$

Washington State Department of Ecology

D. Goswami

B5-18

2 U.S. Environmental Protection Agency

M. Goldstein

B5-01

D. R. Sherwood
28 Pacific Northwest National Laboratory

C. J. Chou

K6-81

R. L. Dirkes

K6-75

P. E. Dresel

K6-96

M. D. Freshley

$\mathrm{H} 0-21$

J. S. Fruchter

M. J. Hartman

K9-96

F. N. Hodges

K6-96

D. G. Horton

$\mathrm{K} 6-81$

$\mathrm{K} 6-81$

V. G. Johnson

K6-96

G. V. Last

K6-81

J. W. Lindberg

K6-81

S. P. Luttrell

K6-96

R. B. Mercer

K6-96

D. R. Newcomer

K6-96

K. B. Olsen

K6-96

R. E. Peterson

K6-96

R. M. Smith

K6-96

F. A. Spane, Jr.

K6-96

M. D. Sweeney

K6-81

E. C. Thornton

K6-96

B. A. Williams

K6-81

Information Release Office (7)

K1-06 